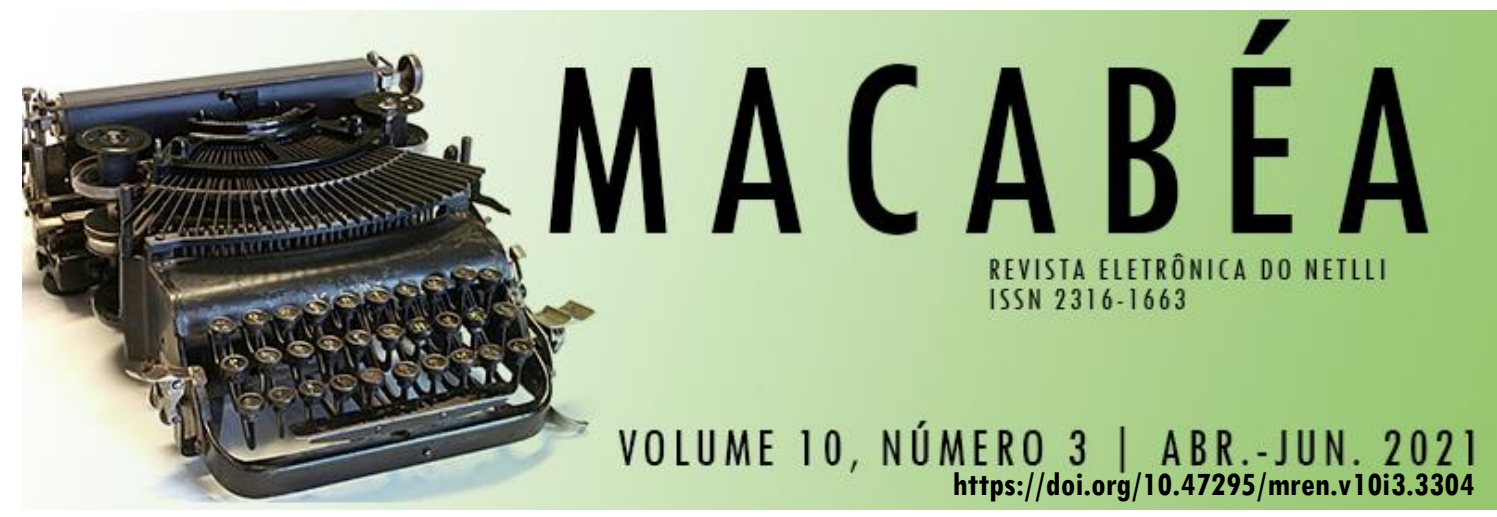

\title{
DESMITIFICAÇÕES DA RELIGIÃO CATÓLICA NA OBRA A COCANHA, DE JOSÉ CLEMENTE POZENATO
}

\section{DEMITIFICATIONS OF THE CATHOLIC RELIGION IN THE WORK $\boldsymbol{A}$ COCANHA, BY JOSÉ CLEMENTE POZENATO}

VALERIA ACOSTA ROY

MÁRCIO MIRANDA ALVES

\section{RESUMO | INDEXAÇÃO | TEXTO | REFERÊNCIAS | CITAR ESTE ARTIGO | OS AUTORES RECEBIDO EM 28/02/2021 • APROVADO EM 08/03/2021}

\begin{abstract}
This article analyses the demystification of the Catholic religion in the novel A cocanha, by José Clemente Pozenato. Based on the concept of myth by Mircea Eliade (2006), it is observed the behavior of the main characters as well as the process in which the religious values of the Italian immigrants are put into question. It is concluded that the mythification of Catholicism, which is materialized in the history and the Catholic theology, takes a different perspective in the fictional narrative as it emphasizes the human side of the social group undermining their "sacred" side.
\end{abstract}

\section{Resumo}

Este artigo analisa a desmitificação da religião católica no romance $\mathbf{A}$ cocanha, de José Clemente Pozenato. A partir do conceito de mito de Mircea Eliade (2006), observa-se o comportamento das principais personagens e a forma como ocorre o processo de questionamento dos valores religiosos dos imigrantes italianos. Concluise que a mitificação do Catolicismo que se concretiza na história e na teologia recebe na narrativa ficcional uma perspectiva diferente a partir da humanização do grupo social. 


\section{Entradas para indexação}

KEYWORDS: Myth. Catholicism. Italian immigration. José Clemente Pozenato.

PALAVRAS-CHAVE: Mito. Catolicismo. Imigração italiana. José Clemente Pozenato.

\section{Texto integral}

\section{INTRODUÇÃO}

No final do século XIX, a Itália atravessava tempos turbulentos e críticos devido à crise econômica, política e social ocasionada pelo auge industrial e o crescimento demográfico exponencial que ultrapassava o número limitado de empregos. Além da instabilidade econômica, conflitos internos e externos abundavam pelo controle da península itálica resultando em guerras intermináveis. Desse modo, milhares de italianos, principalmente agricultores e obreiros, são obrigados a abandonar sua terra natal, com a esperança de encontrar um futuro melhor, sendo o Brasil um dos destinos da emigração. No entanto, não deixam tudo no continente europeu. E eles trazem consigo seus costumes, tradições, línguas e valores, entre os quais a religião católica ocupa um lugar importante.

Desde esse momento, muitos historiadores e romancistas têm registrado esse acontecimento histórico de diferentes maneiras. José Clemente Pozenato é um dos autores que, por meio de sua literatura ficcional, representa o processo histórico da imigração italiana na região nordeste do Rio Grande do Sul. A obra A cocanha (2000) narra a saída, viagem e estabelecimento no Brasil de várias famílias italianas que, em busca de um futuro melhor, chegam à nova terra. 0 romance constitui a primeira parte da trilogia composta ainda por 0 quatrilho (1985) e A babilônia (2006), que dão sequência à narrativa da vida dos descendentes dessas famílias. As três obras são uma referência fundamental na literatura gaúcha no que tange ao estudo da imigração italiana.

É possível afirmar que A cocanha apresenta um teor de crítica social na medida em que revela contradições entre as ações dos personagens religiosos e os princípios católicos que professam. Assim, o colono italiano católico aparece na ficção como um sujeito comum, com qualidades e defeitos, muito longe da imagem idealizada que predomina em alguns discursos historiográficos e literários ao apresentá-lo como um modelo exemplar a ser seguido por seus valores católicos. ${ }^{1}$

Essa visão transgressora do discurso idílico do Catolicismo no romance é confirmada pelo próprio autor da trilogia. Ao se referir a 0 quatrilho (1985), Pozenato reconhece que ante a tarefa de criar sua literatura se encontrava frente a

\footnotetext{
${ }^{1}$ Um exemplo de depoimento que exalta a religião católica do imigrante italiano vem do primeiro bispo da Diocese de Caxias do Sul, José Barea (1893-1951), que ao se dirigir ao colono imigrante, afirma: “[...] nunca te deixaste iludir pelos que, comodamente instalados nas cidades ou nos centros construídos com o teu suor, te apresentavam uma doutrina diferente daquela que te ensinava o sacerdote, que veio desde o começo condividir contigo a mesma vida cheia de dificuldades, de dores e de sacrifícios. E por isso tu sempre refugaste, com toda a força da tua alma crente de vêneto-lombardo, toda manobra intencionada a roubar-te o tesouro mais precioso trazido da Itália: a Religião católica, apostólica e romana" (BAREA, 1995, p. 14, grifos nossos).
} 
duas vertentes: uma representante da história oficial reconhecida e respaldada pelas instituições públicas, ${ }^{2}$ e outra "clandestina", transgressora dessa história exemplar. Segundo Pozenato, por instinto o romancista vê-se atraído à segunda vertente porque é aí onde se percebe "o conflito do indivíduo frente à ordem social em que vive. Mais que isso, é possível questionar essa mesma ordem, cujos valores são protegidos pelas instituições, revelando tanto a sua consistência quanto as suas contradições" (POZENAT0, 1999, p.113-114). Embora na literatura de Pozenato se percebam certos traços que claramente formam parte do imaginário coletivo ${ }^{3} \mathrm{da}$ imigração italiana, as características que deliberadamente sobressaem no decorrer de todo o romance são aquelas que se afastam dessa efígie comumente retratada. Nesse sentido, pode-se interpretar que a ficção de A cocanha desmitifica certos discursos que conformam os costumes do imigrante, principalmente aqueles relacionados às práticas religiosas.

\section{O MITO COMO UMA “HISTÓRIA SAGRADA”}

O termo "mito" tem sido portador de vários significados ao longo da história. Essa mudança semântica percebe-se especialmente quando olhamos para o século XIX, quando o mito se entendia como uma ciência primitiva em oposição à ciência moderna. ${ }^{4}$ No entanto, desde o século XX uma perspectiva nova sobre o assunto começou a ser desenvolvida. Assim, o mito, em vez de ser considerado um substituto da ciência para explicar fenômenos da natureza inexplicáveis em sociedades "primitivas", passou a ter outras funções que vão além, tornando-se um tema válido para ser estudado no âmbito científico (SEGAL, 2004, p. 3). Desse modo, o mito deixa de estar confinado a relatos mitológicos da antiguidade, para passar a existir também nas histórias atuais. São os mitos seculares modernos que estão permeados na vida dos homens, como Robert Segal explica: "histórias sobre heróis estão em todos lados acerca de meros seres humanos, mas esses humanos são elevados a uma

\footnotetext{
${ }^{2}$ Essa vertente reconhecida e respaldada pelas instituições mostra esse processo de mitificação proposto por Eliade (2006, p. 11-16), no qual o mito se manifesta como uma história sagrada, verdadeira e viva que molda e guia a conduta humana até os dias de hoje.

3 Segundo Pesavento (2006, n.p.), o imaginário representa: “[...] o abstrato, o não-visto e nãoexperimentado. É elemento organizador do mundo, que dá coerência, legitimidade e identidade. É sistema de identificação, classificação e valorização do real, pautando condutas e inspirando ações. [...] é sempre um sistema de representações sobre o mundo, que se coloca no lugar da realidade, sem com ela se confundir, mas tendo nela o seu referente". Se nos detemos um pouco a pensar sobre essa definição de "imaginário" como uma maneira de perceber a realidade, não é difícil observar novamente sua clara conexão com aquela definição de mito segundo o filósofo Eliade (2006, p. 16) e do antropólogo Malinowski (2014, posição em Kindle 138), na qual o mito, assim como o imaginário, é um fenômeno "vivo", "real" e "verdadeiro", uma vez que sua influência na percepção da realidade ainda continua vigente na atualidade, guiando e motivando a conduta dos homens.

${ }^{4} \mathrm{O}$ antropólogo inglês E. B. Tylor (1832-1917) é um dos pioneiros exponentes clássicos desse pensamento ao classificar o mito como um objeto de estudo incompatível com a ciência (SEGAL, 2004, p. 14).
} 
altura acima de seres comuns mortais a tal ponto de se tornarem deuses virtuais [...]" (SEGAL, 2004, p. 46). ${ }^{5}$

Essa perspectiva conceitual de Segal sobre o mito é o que nos interessa abordar neste trabalho, o qual vai ao encontro das ideias do filósofo e historiador das religiões Mircea Eliade. Para este, o mito conta "uma história sagrada" que "equivale a revelar um mistério, pois as personagens do mito não são seres humanos: são deuses ou Heróis civilizadores". (ELIADE, 1992, p. 84).

Segundo Eliade, por ser o mito "uma história sagrada", conforma um elemento "vivo", uma vez que apresenta funções na sociedade que influenciam a conduta do homem. Uma dessas funções é proporcionar motivação para lidar com as adversidades enfrentadas no dia a dia. No caso das personagens de A cocanha, as histórias "sagradas" servem para fornecer estímulo para ter êxito na "conquista" de uma terra inexplorada. (ELIADE, 2006, p. 125). Assim, nesse processo de mitificação ocorre um enaltecimento excessivo do objeto em questão, neste caso, tanto da religião católica como do imigrante italiano praticante dessa religião.

Ao mesmo tempo, por ser o mito essa força estimuladora para o homem desafiar seus próprios limites, ele funciona também como um modelo exemplar a ser seguido. Nas palavras de Eliade: "Pelo fato de relatar as gestas dos Entes Sobrenaturais e a manifestação de seus poderes sagrados, o mito se torna o modelo exemplar de todas as atividades humanas significativas" (ELIADE, 2006, p. 12), providenciando, assim, "modelos para a conduta humana, conferindo, por isso mesmo, significação e valor à existência” (ELIADE, 2006, p. 8).

O homem que, portanto, deseja obter a mesma glória que seus antepassados, repete os mesmos atos, ritos, costumes, tradições, etc., com o objetivo de alcançar esse mesmo reconhecimento e sucesso. 0 mito, por relatar o que aconteceu "in illo tempore", constitui "um precedente exemplar para todas as ações e 'situações' que, depois, repetirão este acontecimento" (ELIADE, 2008, p. 350). 0 que o sujeito faz posteriormente, portanto, será baseado nessas histórias gloriosas, das quais ele também almeja ser parte.

A função do mito de proporcionar um modelo exemplar que dá significado ao ser humano influencia a conformação de certos padrões de comportamento que justificam uma determinada ordem social. Em outras palavras, o mito codifica os valores e as crenças que se tornam normas a seguir pela sociedade. Assim, tradições, regras e rituais são mantidos de geração a geração, tornando o mito "um ingrediente vital da civilização humana; longe de ser uma fabulação vã, ele é ao contrário uma realidade viva, a qual se recorre incessantemente" (ELIADE, 2006, p. 23). ${ }^{6}$

Portanto, é possível observar que da história surge o mito e dele surge a tradição que tem a autoridade necessária para ser respeitada e obedecida. Nesse ponto, seria interessante recorrer ao aporte teórico de Malinowski, que, de igual forma, conecta o mito com o poder da tradição sobre a conduta do ser humano. Por

\footnotetext{
5 "stories about heroes are at face value about mere human beings, but the humans are raised so high above ordinary mortals as to become virtual gods [...]". Todas as traduções do inglês ou espanhol são de nossa autoria.

${ }^{6}$ O antropólogo Bronislaw Malinowski (1884-1942) expressa uma ideia muito similar à da Eliade, ao afirmar que o mito, muito mais de ser uma história fictícia como aquelas que lemos nos romances ou novelas, é uma realidade vivida pelos homens, os quais percebem a história como verdadeira e, portanto, continua influenciando o mundo e o destino da humanidade na atualidade. (MALINOWSKI, 2014, Posição em Kindle 138).
} 
ser o mito tão antigo (uma história que conta as origens), ele tem poder no presente para estabelecer as normas de conduta do ser humano:

\begin{abstract}
A função do mito, brevemente, é fortalecer a tradição e dotá-la de maior valor e prestígio remontando-a a uma realidade passada superior, melhor, e supernatural dos eventos iniciais. 0 mito é, portanto, um ingrediente indispensável de toda a cultura. (MALINOWSKI, 2014, posição em Kindle 845-848).7
\end{abstract}

Desse modo, é possível afirmar que o mito, como um elemento vivo, se encontra presente em diversos processos mitificadores na contemporaneidade, como em figuras históricas, celebridades, etnias, nacionalidades e ideologias, para mencionar somente alguns exemplos. 0 Catolicismo dos imigrantes italianos, com certeza, não foge desse processo.

Nesse sentido, é possível perceber como, com base nesse entendimento de mito, o romance A cocanha realiza a desconstrução de vários mitos sobre a imigração italiana, sendo a religião católica um deles. As histórias sagradas são transformadas em narrações comuns com personagens comuns, cujos atos estão muito distantes dos discursos laudatórios proeminentes na historiografia, na literatura e na oralidade dos descendentes de italianos na atualidade. Assim, a narrativa ficcional questiona o caráter sacro da religião católica italiana, rompendo com o processo de mitificação tão presente na memória coletiva.

\title{
3. MITIFICAÇÕES DA FÉ CATÓLICA
}

Desde o século IV, quando o imperador Constantino aceita e oficializa o Cristianismo em seu governo como uma estratégia para unificar o império romano, o processo de mitificação da religião católica começa a ocorrer. Nesse momento surge o primeiro acordo histórico entre o poder litúrgico e o poder imperial.

Após o Edito de Milão reconhecer a religião cristã como legítima no Império Romano (313), Constantino o Grande tornou-se o primeiro Imperador que apoiou a igreja e por razões políticas tornou-se um forte defensor da unidade hierárquica da igreja. (DE CHIRICO, 2015, posição em Kindle 429-431).8

\footnotetext{
7 "The function of myth, briefly, is to strengthen tradition and endow it with a greater value and prestige by tracing it back to a higher, better, more supernatural reality of initial events. Myth is, therefore, an indispensable ingredient of all culture”. Segal também comenta que, para Malinowski, o mito pode ser interpretado como uma ideologia uma vez que proporciona uma justificação para a submissão na sociedade. "For Malinowski, myth is like ideology in justifying submission to society." (SEGAL, 2014, p. 129).

8 "After the Edict of Milan had recognized the Christian religion as legitimate in the Roman Empire (313), Constantine the Great became the first Emperor that supported the church and for political reasons became a strong advocate of the hierarchical unity of the church". Blainey (2012, p. 65) concorda com esse pensamento afirmando que essas razões visavam a unir uma população diversa: "Foi oficialmente
} 
Por outro lado, esforços para formar uma identidade italiana católica também cumprem um papel importante na visão exaltada do Catolicismo. No século XIX, a Itália ainda não era uma nação independente, disputada tanto por diferentes reinos da península como também por outros países como a França e a Áustria. Assim, após a queda de Napoleão, o período que vai de 1815 a 1870 caracteriza-se por esforços de parte do papado para restabelecer a autoridade que havia perdido durante a ocupação francesa. Como resultado, a nobreza volta do exílio a seus postos de origem prévios à revolução, assim como também o próprio papa Pio VII regressa a Roma (PIERRARD, 1982, p. 224). O Vaticano, assim, assume uma nova missão de propagar na população da península um sentimento religioso com o fim de criar uma identidade italiana, essencialmente católica, como uma maneira de combater as forças do liberalismo (vestígios que tinham ficado do Iluminismo) que tanto ameaçavam a Instituição Católica. Esses esforços parecem ter êxito na medida em que, no século XIX, a Igreja Católica continua sendo uma grande influência tanto sobre as classes altas da sociedade, que ainda possuíam "uma sexta parte de todas as terras férteis na Itália" (MARTINA apud KERTZER, 2000, p. 187) ${ }^{9}$, como nas classes mais baixas, que conformavam a maior parte da população italiana e para os quais "a Igreja e o Catolicismo constituíam uma parte central da vida diária. [...] era a Igreja local, o padroeiro local, os ritos que marcavam a vida cíclica agrária do camponês italiano [...]" (KERTZER, 2000, p. 182). ${ }^{10}$

0 processo de mitificação do Catolicismo não se limita à história do continente europeu. No Brasil, a igreja católica também cumpre um papel extremamente importante. Desde a chegada dos primeiros portugueses, no século XVI, o Catolicismo faz-se presente com os jesuítas, os quais, apoiados pelo sistema de Padroado ${ }^{11}$, vêm com a missão de catequizar a população nativa. (CORDEIRO, 2016, p. 129-156). Três séculos mais tarde, os imigrantes italianos trazem consigo a religião de seus ancestrais e, assim, a religião católica cumpre uma série de funções cruciais para o êxito de seu estabelecimento na nova terra.

Primeiramente, a fé servia como um elemento unificador, já que embora os colonos viessem de diferentes regiões da Itália, com diversos costumes, tradições e dialetos, o Catolicismo era o denominador comum que proporcionava a unidade

reconhecido que o cristianismo, por ser aberto a todas as etnias, poderia funcionar como um fator de unificação em um império multirracial".

9 "Despite the massive loss of property as a result of the sale of Church holdings early in the century, by the mid-nineteenth century the Church still owned a sixth of all productive lands in Italy. Another consistent source of displeasure was the great opulence on display in Rome, where cardinals - themselves often from the nobility - travelled in lavish carriages surrounded by liveried attendants, making frequent social visits to noble families".

10 "For the mass of Italians, the Church and Catholicism were a central part of everyday life. More important than the activities of the pope and the cardinals in Rome for them was the local parish church, the local patron saint, the rites that marked the agricultural cycle and the life cycle [...]." Cabe notar que essa religiosidade dos camponeses se identifica com a representação deles em $A$ cocanha.

${ }^{11}$ Os reis portugueses receberam do papa o direito do Padroado que consistia no sustento econômico pelo papado na troca do compromisso do rei em levar o Catolicismo às terras conquistadas. Era concedido ao rei a tarefa de recolher os dízimos eclesiásticos para sustentar o clero e os templos. Ao mesmo tempo, o monarca devia nomear os clérigos, cabendo aos bispos apenas a sua confirmação. (POSSAMAI, 2005, p. 53-54). 
para a reconstrução de uma nova identidade (MANFROI, 1975, p. 153). Em segundo lugar, a religião católica proporcionava ao colono imigrante uma maneira de lidar com o sofrimento inevitável de adaptação a uma terra desconhecida e cheia de desafios (COCCO, 2008, p. 13) ${ }^{12}$. Finalmente, ser católico dentro da comunidade italiana constituía um símbolo de status. Ser parte dos rituais católicos não somente tornava o devoto um "bom cidadão" e uma pessoa aceita pela comunidade religiosa, mas também garantia um lugar de estima e valor na estrutura social italiana. Desse modo, a capela e a presença do sacerdote eram elementos essenciais que davam prestígio às novas colônias (MANFROI, 1975, p. 157).

A construção de uma imagem mitificada do Catolicismo não se deve somente a seu contexto histórico, mas também à teologia, que cumpre sua parte nesse processo. Com base no trabalho de De Chirico, segundo Allison (2014, posição em Kindle 898-900), o Catolicismo teologicamente está fundamentado no princípio doutrinal chamado "interdependência da natureza-graça"13, o qual significa que a natureza e a graça trabalham em uma relação de interdependência mútua. Ou seja, os elementos da natureza (como por exemplo o pão e o vinho) servem como canal pelo qual a graça de Deus é transmitida ao ser humano (ALLISON, 2014, posição em Kindle 912-914).

Esse aspecto teológico do Catolicismo pode ajudar a entender em parte porque existe uma grande ênfase nos rituais e como isso naturalmente engrandece o papel dos objetos e a figura do sacerdote por ser o único responsável em administrá-los. Nodari e Cescon (2009, p. 82) concordam a postura de exaltação da figura do padre, referindo-se a ele da seguinte maneira: "No serviço do ministro ordenado é o próprio Cristo que está presente a sua Igreja enquanto Cabeça de seu Corpo, Pastor de seu rebanho, Sumo Sacerdote do sacrifício redentor, mestre da Verdade". (grifos nossos). Note-se os adjetivos usados pelos autores para se referirem ao sacerdote: "Cristo", "Cabeça", "Pastor", "Sumo Sacerdote", "mestre da Verdade". Claramente todos eles enaltecem o papel do padre na Igreja Católica, colocando-o acima dos fiéis e no mesmo nível que o próprio Jesus Cristo. Por conseguinte, o cumprimento dos sacramentos ${ }^{14}$ resulta essencial na doutrina católica, gerando naturalmente no devoto uma preocupação em fazer parte deles, sem que necessariamente precise entender o motivo de sua realização e muito menos ter convicção das razões de sua própria fé. ${ }^{15}$

\footnotetext{
12 Segna define essa atitude católica tradicionalista como uma maneira de justificar a aflição. Nas suas palavras: "O sofrimento (falta de alimentação, de poder de decisão, de liberdade de expressão) é considerado de um particular ponto de vista: quanto mais a gente sofre, tanto mais se purifica e consegue a paz eterna". (SEGNA, 1977, p. 95)

13 "nature-grace interdependence".

${ }^{14}$ Segundo a doutrina católica, há sete sacramentos: batismo, crisma, eucaristia, penitência, unção dos enfermos, ordem e matrimônio. Por meio da administração dos sacramentos, o católico recebe uma infusão de graça, a qual o torna mais santo. (ALLISON, 2018, n.p.)

15 Os autores De Boni e Costa destacam a forte tendência do Catolicismo popular ao ritualismo, a tal ponto que a maneira de medir a religiosidade de uma pessoa ocorre por meio de sua presença e prática nos diferentes rituais, sem existir o conceito de conversão. Como eles afirmam: "Este catolicismo popular brasileiro [...] caracteriza-se por um forte ritualismo. Ao invés de insistir nisto que a linguagem teológica chama de conversão, dá-se importância fundamental à presença física nas cerimônias e à realização mecânica dos atos religiosos. O critério de pertença à religião mede-se pela assistência [...].” (DE BONI; COSTA, 1984, p.123, grifo do autor). Segna (1977), ao definir o ritualismo no contexto da religião católica, também adverte sobre esse perigo, uma vez que a ênfase nas práticas rituais pode anular o significado da
} 
Finalmente, a mitificação da doutrina católica, seja na perspectiva histórica ou teológica, também se manifesta nos escritos da literatura e nos discursos oficiais, como nas organizações das instituições públicas e privadas. À narrativa ficcional cabe o papel de problematizar e, por que não, questionar esses comportamentos que muitas vezes fazem parte do imaginário, mas que não resistem a um confrontamento entre teoria e prática social. É isso que propõe a narrativa ficcional de A cocanha.

\section{DESMITIFICAÇÃO DAS VIRTUdES E HUMANIZAÇÃO DE HOMENS E MULHERES}

Existem vários elementos no romance A cocanha que desmitificam a religião dos imigrantes, e um deles ocorre na figura retórica da ironia utilizada pelo narrador para apresentar as virtudes cristãs ${ }^{16}$ de uma maneira contraditória. Assim, características como a fortaleza, a paciência e a fé são desconstruídas, já que em vez de ser representadas como atributos contribuintes de seu sucesso, são representadas como obstáculos. De acordo a Moisés (2004, p. 247), “[...] a ironia resulta do inteligente emprego do contraste, com vistas a perturbar o interlocutor [...].". Esse contraste já se faz evidente no título do próprio romance A cocanha, ${ }^{17}$ que alude à colisão que existe entre as expectativas idealizadas dos colonos religiosos e a situação adversa com a qual eles se deparam ao chegar a seu destino. Do mesmo modo, algumas virtudes dos colonos, como a fortaleza, a paciência e a fé, entre outras, também aparecem representadas com certa ironia. Isso ocorre porque embora tais características sejam reconhecidas pela Igreja Católica como atributos positivos, seus portadores não usufruem nenhum benefício deles, pelo contrário, eles perpetuam sua desfortuna, sendo assim representados de forma conflitante.

Um exemplo no qual a ironia é claramente perceptível na representação das virtudes cristãs ocorre na resposta indiferente da Igreja frente à situação desfavorável da mulher dentro de seu lar. Esse aspecto é perceptível na atitude de Giulieta, uma mulher vítima da agressão física e verbal de seu marido por não gerar filhos homens para ajudar no trabalho da lavoura. Quando ela recorre ao padre em

prática religiosa e, portanto, impedir qualquer transformação verdadeira. Em suas palavras: “O ritualismo é uma característica da religiosidade popular e consiste na repetição acrítica das práticas. A simples repetição bloqueia a significação dos ritos e dos símbolos neles contidos. O contexto ritualista situa as pessoas à margem da vida porque omite a dimensão horizontal ou social. Quanto mais ritualista é uma Igreja, menos lembra os valores e menor é sua força transformadora da sociedade". (SEGNA, 1977, p. 147)

${ }^{16}$ Segundo Allison (pp. 339-400), o Catecismo da Igreja Católica afirma que existem dois tipos de virtudes: as humanas e as teológicas. A primeira categoria comporta: "a prudência ("a razão correta em ação"), a justiça (dar a Deus e aos homens o que é devido), a fortaleza (perseverança na dificuldade e na busca do bem), e temperança (moderação nos prazeres). Por outro lado, as virtudes teológicas são orientadas a Deus, sendo: a fé, a esperança, e a caridade (amor)." (ALLISON, 2014, posição em Kindle 8767). Essas virtudes representadas nos personagens religiosos da obra aparecem completamente desconstruídas na medida em que seus portadores levam vidas desgraçadas e sem esperança.

${ }^{17}$ Según Boniatti (2004, p. 125), o término "cocanha" foi "documentado pela primeira vez no século XII, para designar um modelo de sociedade utópica, [que] relaciona-se com a fartura e a fruição plena dos prazeres materiais. E é na confluência da História da Imigração Italiana que, na segunda metade do século XIX essa utopia foi difundida entre a população pobre da Itália”. 
busca de ajuda, o único conselho que recebe é de resignar-se a sua situação: “Giulieta foi falar com o padre, que lhe recomendou paciência e oração, pois não havia outra coisa a fazer, era a cruz que lhe cabia carregar. Todos os dias ia à igreja e passava uma hora rezando, preparando-se para voltar a encarar o seu destino" (POZENATO, 2000 , p. 262, grifos nossos). Esse conformismo de parte da mulher imigrante italiana frente a seu sofrimento, apoiado pela igreja católica, já se apresenta no começo do romance quando a opinião de Giulieta sobre emigrar a outro país é completamente ignorada por seu marido, o que a faz se submeter forçadamente ao desejo dele:

\begin{abstract}
Ele não lhe pedira opinião sobre essa viagem para o outro lado do mundo. Não perguntou se ela não se importava de deixar os pais, gastos pela idade, ou se preferia ficar. Disse que iam embarcar, e pronto. Giulieta sentiu-se magoada, mas não protestou, a não ser com o silêncio. [...] $O$ convento lhe ensinara a suportar tudo sem queixas e com resignação. [...] Seu único desabafo eram as lágrimas escondidas. Não tinha muita certeza de haver um lugar no mundo onde ser feliz. (POZENATO, 2000, p. 42-43, grifos nossos).
\end{abstract}

Desse modo, a falta de participação de Giulieta em uma decisão que mudaria sua vida indica não apenas submissão, mas também conformidade e resignação. Afinal, aprendera no convento a aceitar a tudo como resultado da vontade divina, contra a qual não se deve levantar.

Além da representação questionadora da resignação na mulher imigrante devota, o sofrimento aparece como outro elemento crucial na representação desmitificada da fé dos colonos. 0 filósofo Ludwig Feuerbach, apresenta o sofrimento como um conceito estreitamente relacionado ao cristianismo:

[...] todos os pensamentos e sentimentos que inicialmente se associam a Cristo concentram-se no conceito de sofrimento [...] as imagens do crucificado, que até hoje encontramos em todas as igrejas, não representam um redentor, mas somente o crucificado, o sofredor. (FEUERBACH, 1997, p. 104-106).

A maioria das figuras femininas no romance de Pozenato são mulheres religiosas e, portanto, portadoras de virtudes cristãs. No entanto, assim como ocorre com Giulieta, todas elas são representadas como seres miseráveis e infelizes. A personagem de Rosa poderia ser outro exemplo que desmitifica a religião dos imigrantes, ao ser caracterizada tanto pelo seu sofrimento como também pela sua forte devoção católica. Já essa imagem desventurada de Rosa é transmitida pela voz narrativa ao descrevê-la da seguinte maneira: "Rosa era a que mais sofria, a pobrezinha, a que mais tinha envelhecido. Tinha a metade dos cabelos brancos, com pouco mais de trinta anos, e já usava lenço na cabeça como uma velha". (POZENATO, 2000 , p. 325). Os personagens também a descrevem de uma maneira similar. 0 padre Giobbe, por exemplo, lembra dela da seguinte maneira: "Essa pobre menina 
Rosa, por exemplo. Apenas trinta anos e cheia de rugas, a boca quase sem dentes, os fios brancos de cabelo que o lenço deixava escapar" (POZENATO, 2002, p. 336).

Por outro lado, o sofrimento resulta evidente não só na descrição física desfavorável das mulheres religiosas, mas também em suas próprias vivências em família. Um episódio que mostra a aflição como um atributo esperado do devoto ocorre quando Rosa recebe em sua casa seu marido alcoolizado. 0 estado de Aurélio é tão crítico que seu amigo Antônio precisa carregá-lo até sua própria cama. A única reação de Rosa ante esse cenário lamentável é de sofrimento e resignação expressados em sua fé à Madona: "Antônio foi embora e ela ajoelhou-se ao lado da cama, chorando baixinho. 0 cheiro da bebida lhe provocava náuseas. Só e desamparada, ergueu os olhos para o quadro da Madonna e rezou até se sentir aliviada do sofrimento." (POZENATO, 2000, p. 207).

Além de Rosa, Aurora é outro exemplo de mulher religiosa que evidencia a desconstrução da religião católica em sua caracterização miserável. 0 narrador a apresenta da seguinte maneira: "Parecia doente, o rosto cheio de rugas, os olhos fundos". (POZENATO, 2000, p. 214). Assim como Rosa, o sofrimento de Aurora pelo desaparecimento de sua filha Chiara parece ser aceito por ela com certa resignação até o ponto de chegar a assumir culpabilidade por não ser ouvida por Deus. Então, mais uma vez aparece essa relação entre religiosidade e sofrimento tão característica na doutrina católica ao se considerar um atributo necessário para alcançar o favor de Deus:

Eu quero que tu rezes por ela, porque eu cansei de rezar e Deus não me ouve. Acho que é porque eu sou a culpada, ele não pode me ouvir. Mas ele vai te ouvir, tu es a melhor amiga da Chiara. E agora tens a força de mãe do primeiro filho. Reza para Nossa Senhora, a Chiara precisa muito. (POZENATO, 2000, p. 215).

Por outro lado, é interessante notar o recurso estilístico da ironia empregado pelo narrador até na escolha do próprio nome de sua personagem "Aurora", uma vez que sua caracterização não pode estar mais longe da ideia de esperança ou de um novo começo. Pelo contrário, sua realidade está cercada de tragédia e miséria. ${ }^{18}$ Dessa maneira, a figura retórica da ironia mais uma vez é usada para retratar, de uma maneira sutil, as contradições que existem no universo religioso do imigrante italiano. Rangel (2004, p.168) explica essa estratégia utilizada pelo autor: "As possibilidades, esperanças e verdades da existência humana, no interior do universo colonial italiano, são observadas ironicamente, quando cria um ambiente de

\footnotetext{
${ }^{18}$ É interessante notar que, em relação a esse perfil sofredor da mulher imigrante italiana, existe uma correlação entre a representação ficcional de Pozenato e a representação de registros históricos. Um exemplo dessa consistência histórica pode-se ver nos escritos da historiadora Giron (1998, p. 92), que num de seus textos descreve as mulheres italianas da seguinte maneira: "As nossas avós imigrantes eram tristes, lembrando as desventuradas mulheres das tragédias gregas. Antígonas, Medeias e Agaves chamavam-se Marias, Teresas e Rosas. Em seus olhos as mensagens do sofrimento passado mesclavam-se com uma certa saudade pelas do futuro". A historiadora continua em sua reflexão: "Todas as avós que conheci, ricas ou pobres, urbanas ou colonas tinham um ponto comum: eram muito tristes, de uma tristeza que jazia no fundo dos olhos, uma saudade que parecia não ter remédio”. (GIRON, 1998, p. 93).
} 
inadequação última da consciência para viver feliz naquele mundo ou compreendêlo plenamente".

Outro elemento que desmitifica a religião católica no romance $\mathbf{A}$ cocanha exprime-se na atribuição de características que dessacralizam o caráter do colono devoto italiano, levando-o a um processo de humanização. Pelo termo "humanização" entende-se a representação do imigrante italiano como um ser humano limitado e frágil, portador de atributos que se opõem à imagem sacra e exemplar do devoto italiano. Esse sentido da palavra assemelha-se ao significado do termo flesh (carne), definido no Holman bible dictionary (1991): "Biblicamente, a carne é vista como a criação da natureza humana. Não é automaticamente pecadora, mas é débil, limitada e temporal. Essas qualidades a fazem vulnerável ao pecado". (HOLMAN BIBLE DICTIONARY, p. 498). ${ }^{19}$ Esse processo de humanização representado no romance consegue expor as fraquezas dos personagens religiosos, ou seja, sua vulnerabilidade como seres humanos, ampliando, assim, a verossimilhança da representação ficcional.

O caráter humano falho revela-se especialmente na representação das figuras masculinas frequentadoras de igreja, personagens que aparecem da seguinte maneira: Antônio, como abusador de sua esposa; Domênico, como mulherengo; Aurélio, como alcoólatra, e Ambrósio, como comerciante desonesto. Assim, os valores católicos, no romance de Pozenato, são postos à prova, expondo o lado menos nobre de seus praticantes e, portanto, revelando uma representação crítica da religião católica.

0 personagem de Aurélio, esposo de Rosa, constitui um exemplo claro dessa representação crítica da religião dos imigrantes. Embora seja um homem religioso, Aurélio é retratado no romance como uma figura fracassada por seu vício à bebida. O começo de sua compulsão já se mostra no momento da construção das primeiras casas, quando todos os homens em seu descanso se reúnem para beber: "O moço Aurélio, de seu lado, toma um gole e faz uma careta, mas seu olhar fica na espreita, ansioso para que a garrafa volte a suas mãos. Nicola abana a cabeça, sente que Aurélio está atraído pelo veneno, como mosca pelo mel". (POZENATO, 2000, p. 135). Esse "veneno" termina destruindo a vida do personagem porque "começa a comer por dentro, até o homem virar um trapo". (POZENATO, 2000, p. 135). Inevitavelmente, a família de Aurélio é também tragicamente afetada, uma vez que além de ser testemunha da miséria de um ser querido, torna-se igualmente vítima das consequências destrutoras da bebida.

No entanto, Aurélio não é o único homem atingido pela adição da bebida, nas palavras de Gema dirigindo-se a Rosa: "Não é só o Aurélio. O maior negócio do Miro é vender cachaça. Deviam botar fogo naquele chiqueiro. Ou proibir de vender cachaça. Ela está acabando com os homens da colônia" (POZENATO, 2000, p. 203).

\footnotetext{
19 "Biblically, the flesh is viewed as the created and natural humanity. It is not automatically sinful, but it is weak, limited, and temporal. Such qualities make it vulnerable to sin". Por outro lado, no mesmo dicionário aparece o seguinte trecho sob o termo "antropologia", que parece se complementar bem com o sentido de "humanização" utilizado nesta análise: "Human beings are frail and sinful. The Bible affirms both explicitly and implicitly the weaknesses and shortcomings of human beings. Manifest as both physical weakness and spiritual failing, this frailty is seen properly in contrast to the holiness and righteousness of God. The condition of humanity leads to the conclusion that all individuals are dependent upon God and that salvation truly is a matter of God's grace not human effort or striving" (HOLMAN, 1991, p. 62).
} 
0 vício da bebida aparece claramente no romance como um elemento desmitificador do homem imigrante religioso, revelando sua fraqueza, seu lado humano que se contrapõe à imagem sacralizada do devoto italiano. Nesse sentido, desde uma perspectiva filosófica, a função de um modelo a seguir que apresenta o mito, segundo Eliade (2006, p. 12), aparece totalmente desconstruída. A moral do Catolicismo, como herança digna de ser mantida por futuras gerações, cai por terra ao mostrar a vida miserável de seus seguidores.

Outro personagem masculino que desconstrói a fé do imigrante italiano é Domênico, um pai de família católico que decide deixar sua esposa e filhos para embarcar numa viagem à América, aventurando-se não apenas em busca de uma melhoria financeira, mas também em busca de aventuras amorosas. Essa incoerência entre os princípios católicos e os atos do praticante revela-se na voz narrativa, referindo-se a Domênico e a sua nova vida libertina no Brasil da seguinte maneira:

\begin{abstract}
Estava recuperando o tempo perdido por ter se casado muito jovem. Sabia que estava vivendo em pecado, mas prometia a Deus que seria apenas por uma temporada. Logo que estivesse melhor de vida, mandaria vir a mulher e assentaria a cabeça. Pagaria todo o débito de penitência aguentando a sarna até o fim de seus dias. Já que teria de pagar caro, não havia mal nenhum em aumentar a dívida o quanto pudesse. (POZENATO, 2000, p. 162).
\end{abstract}

Nesse caso, os valores católicos são postos em xeque não somente pela dessacralização do modelo familiar religioso, mas também pela escolha consciente do devoto em viver uma vida contrária aos princípios que afirma seguir. Como se observa no comportamento do personagem quando está longe de sua família:

Domênico podia levar a vida como bem quisesse, sem choro de criança e queixas de mulher nos ouvidos. Não deixava de agradecer a Deus por ter tanta sorte, para não se sentir blasfemo. Mas não podia também evitar de sentir orgulho por sua esperteza. Sentia, sim, um vazio. Fazia-lhe falta uma mulher para esperá-lo em casa com agrados. Para ser sincero, começava a enfastiar-se de deitar sempre com uma mulher diferente. Vê só, Domênico, recriminouse, tu te queixando disso. (POZENATO, 2000, p. 226).

Por outro lado, é interessante observar como essa dessacralização da religião católica não somente se observa por meio da exposição da conduta incoerente de seus seguidores, mas também por meio daqueles que negam sê-lo. Roco é um personagem que não se considera católico, no entanto, sua caracterização contrasta àquela de seus conterrâneos religiosos, de uma maneira que expõe suas fraquezas por ser ele quem, paradoxalmente, possui os valores que os outros carecem. Um episódio no qual pode se ver esse contraste ocorre no confronto de Roco com seu amigo católico Ambrósio. A diferença de valores entre os personagens é exposta 
quando Ambrósio conta a Roco a "esperteza" de seu patrão por roubar seus fregueses, colocando um gancho de ferro na balança no momento de pesar a mercadoria a ser vendida. A reação de Roco ao escutar Ambrósio é claramente de indignação: "Discutiram, porque essa safadeza deixava Roco furioso. Mais ainda o enfurecia ouvir o Ambrósio dizer que isso não era desonestidade, era esperteza." (POZENATO, 2000, p. 146). Esses perfis opostos se intensificam quando Ambrósio responde à desaprovação de Roco da seguinte maneira:

- Pára, Roco. Não vem com sermão. Não para cima de mim.

- Que eu saiba, quem anda atrás dos padres es tu, não sou eu. Quem gosta de sermão és tu.

Ambrósio deu na mesa um soco que fez saltar os pratos. Foi a vez de Roco rir. (POZENATO, 2000, p. 146- 147)

No entanto, essa desmitificação que se observa no caráter de Ambrósio não ocorre apenas por meio da incongruência dos atos e das crenças dos personagens devotos representados. Existe também um questionamento sobre a irracionalidade do ritualismo católico exercido por esses personagens, os quais não conseguem captar as mensagens ritualísticas. Isso ocorre quando, por exemplo, Roco participa em uma missa e não consegue entender seu significado: "Ajoelhado no banco do lado dos homens, Roco tentava não bocejar. A missa não lhe dizia nada, com o palavrório em latim". (POZENATO, 2000, p. 353). 0 questionamento dos rituais católicos se intensifica ainda mais no fato de que embora se perceba um interesse espiritual genuíno por parte do personagem, a Igreja falha em suprir essa necessidade:

O sermão costumava ser ainda mais aborrecido com um ranço antiquado que o irritava. Mas tinha descoberto que o evangelho e as epístolas eram bem interessantes, ensinavam mais que o sermão do vigário. Tirou do bolso o livro do Novo Testamento, como se fosse o livro de missa, e pôs-se a ler, compenetrado. (POZENATO, 2000, p. 353).

Nessa passagem, a narrativa indica de certa forma a dessacralização da Igreja junto com seus ritos, na medida em que o sermão do padre não atinge o fiel por falta de compreensão da língua. Para Roco, suas próprias interpretações do Novo Testamento são mais importantes do que as palavras do sermão. 0 padre revela-se o portador de uma mensagem muito diferente daquela que de fato se encontra no Novo Testamento. Isso se vê, por exemplo, quando o sacerdote acusa a maçonaria como o maior inimigo da religião "herdada dos pais". ${ }^{20}$ Sua acusação inclui ainda a autoridade municipal, que, segundo o vigário, "punha todos os empecilhos para ser

\footnotetext{
${ }^{20}$ Essa rejeição contra os maçônicos por parte da Igreja Católica, já começa no século XVIII, quando o Papa Clemente XII em 1738 proíbe aos católicos a filiação a qualquer organização maçônica, como uma estratégia para deter o crescente liberalismo que ameaçava a autoridade eclesiástica. (POSSAMAI, 2005, p. 31-32).
} 
concluída a construção da igreja, semeando a cizânia e a discórdia". (POZENATO, 2000 , p. 354). No entanto, a reação de Roco, mais uma vez, é contrastada com a do padre, ao ser representada da seguinte maneira: "Ele nunca se envolvera com a maçonaria, mas não conseguia entender, nem aceitar, todo esse rancor. Não era isso o que lia no evangelho." (POZENATO, 2000, p. 354). Segundo Roco, o sermão do padre, claramente, discorda das ideias ensinadas nos Evangelhos de amor a Deus e ao próximo. ${ }^{21}$ Os conceitos transmitidos pelo vigário são de rancor, julgamento e condenação. ${ }^{22}$

Cabe notar como esses episódios experimentados por Roco, além de dessacralizar a fé católica por contradizer as próprias Escrituras, trazem também o caráter ritualista como uma possível explicação da incoerência existente entre os atos e as crenças de seus praticantes. Na história já se registra o uso do latim como língua litúrgica oficial na Itália, o que, naturalmente, estimulava o distanciamento entre o sacerdote e a congregação. (POLLARD, 2008, p.12). Essa separação fazia com que a imagem do clérigo fosse enaltecida, levando o leigo a uma atitude passiva e dependente dele em suas práticas litúrgicas, o que inibia sua participação racional e, portanto, levava a uma falta de convicção e transformação de caráter genuínas. ${ }^{23}$ Claramente essa prática de rituais é ressaltada nesse episódio não só pelo uso do latim na missa, mas também pela insistência do vigário em concluir a construção da igreja para levar a cabo esses rituais.

Existem autores que sustentam essa mesma ideia. Segna (1977, p. 147) afirma que a ênfase nos rituais pode anular o significado do próprio ritual quando ocorre uma repetição mecânica sem exigir um raciocínio de parte do praticante, bloqueando inclusive seu poder transformador. De Boni e Costa (1984), junto com Manfroi (1975, p. 185), igualmente observam o forte caráter ritualista da religião católica, enfatizando que um católico praticante era apenas reconhecido pela sua presença física nos rituais, sendo essa a principal, se não a única, característica que o diferenciava de um não católico. Desse modo, não deveria de ser surpreendente que devotos como Aurélio, Domênico e Ambrósio não demostrem nenhum sinal de uma conversão genuína, pelo contrário, sejam retratados como pessoas hipócritas sem convicção alguma sobre sua fé.

Por outro lado, a revelação da humanização nos personagens religiosos não se limita à exposição de sua conduta contraditória ou à ineficácia de seus rituais. 0

\footnotetext{
${ }^{21}$ A mensagem de amor no Novo Testamento pode se ver, por exemplo quando Jesus afirma qual é o mandamento mais importante: 'Ame o Senhor, seu Deus, com todo o coração, com toda a alma e com toda a mente.' Este é o maior mandamento e o mais importante. E o segundo mais importante é parecido como o primeiro: 'Ame os outros como você ama a você mesmo" (MATEUS, 22: 35-39, NTLH, 2000).

${ }^{22}$ Essa ideia de condenação e julgamento claramente se contrapõe à mensagem de Jesus que se encontra nas Escrituras: "Pois Deus mandou o seu Filho para salvar o mundo e não para julgá-lo". (João 3:17, NTLH, 2000).

${ }^{23}$ É interessante notar que a falta de entendimento na realização de rituais cristãos, neste caso, na participação de uma missa presidida em latim, também é rejeitada no Novo Testamento. Como pode se perceber na carta aos romanos, Paulo exorta a seus irmãos: "Rogo-vos, pois, irmãos, pelas misericórdias de Deus, que apresenteis o vosso corpo por sacrifício vivo, santo e agradável a Deus, que é o vosso culto racional. E não vos conformeis com este século, mas transformai-vos pela renovação da vossa mente, para que experimenteis qual seja a boa, agradável e perfeita vontade de Deus" (Romanos 12:1-2, ARA, 1999, grifos nossos). Desse modo, o entendimento e o raciocínio executados por uma mente renovada são requisitos para viver uma vida transformada que se opõe à participação irracional mecanizada de ritos religiosos.
} 
sacerdote, como autoridade eclesiástica, também aparece no romance como um símbolo importante dessa dessacralização ao ser representado como um ser limitado e frágil. É o caso do padre Giobbe, cuja caracterização rompe com a figura sacra e divina normalmente apresentada pela Igreja Católica. Assim, essa imagem do padre como representante de Cristo na Terra, "Cabeça", "Pastor", "Sumo Sacerdote", "mestre da Verdade" (NODARI; CESCON, 2009, p. 82), no romance aparece totalmente desconstruída por apresentar em seu lugar, um homem frágil e vulnerável aos sofrimentos da vida. Esse conflito entre o divino e o humano mostrase nos pensamentos de dúvida e insuficiência que invadem o clérigo frente a situação deplorável dos colonos que esperam dele algum tipo de ajuda divina.

Esta sensação de impotência o assaltava cada vez que via os olhares com que era recebido, como se esperassem dele algum milagre, algum remédio para o sofrimento. Percebia que tocavam nele as escondidas, quando estava no meio das pessoas, quem sabe imaginando que saísse dele alguma energia para realimentar suas almas cansadas. (POZENATO, 2000, p. 337)

Cabe notar como nesta passagem existe uma analogia com um episódio muito similar do Novo Testamento no qual se observa uma aproximação entre o caráter divino do padre Giobbe e o caráter divino de Jesus. Nessa história bíblica, Jesus ao caminhar em meio à multidão percebe poder saindo dele no momento em que uma mulher toca seu manto com a esperança de ser sarada de uma doença que a afligia fazia 12 anos. Após a mulher ser sarada, Jesus diz:

- Quem foi que me tocou? [...] - Alguém me tocou, pois eu senti que de mim saiu poder. Então a mulher, vendo que não podia mais ficar escondida, veio, tremendo, e se atirou aos pês de Jesus. [...] Aí Jesus disse: - Minha filha, você sarou porque teve fé! Vá em paz. (LUCAS, 8:45-48, NTLH, 2000)

Esse paralelismo entre Jesus e o padre Giobbe é evidente. No entanto, no romance essa semelhança é rapidamente desconstruída na manifestação do caráter humano do clérigo, que se sente incapaz de ajudar os colonos na situação lamentável na qual se encontram. "Pobre gente. Mal sabiam quanto ele também se sentia fraco. Mas se a presença dele servia de algum conforto, não iria decepcioná-los, passaria o resto dos seus dias no lombo da mula" (POZENAT0, 2000, p. 337, grifo nosso). Essa inadequação de parte do padre se compensa com sua vontade humana de ajudar as pessoas, mesmo que seja cavalgando no lombo de uma mula.

É interessante notar como o caráter sacro outorgado ao sacerdote sustentase no sistema hierárquico da doutrina católica que, como já foi mencionado, eleva o papel do clérigo enquanto outorga ao leigo um lugar passivo. Esse aspecto pode-se ver no romance quando o padre, ao passar em frente a uma bodega, percebe os olhares dos homens fixos sobre ele: "Padre Giobbe sabia que isso não era 
indiferença. Era respeito, temor" (POZENATO, 2000, p. 337). No entanto, a humanização do vigário novamente é destacada no romance quando seus sentimentos a respeito dessa reverência são descritos pelo narrador como: "Um respeito e um temor excessivos, que ele gostaria de ver trocados por uma afeição mais humana" (POZENATO, 2000, p. 337, grifos nossos). Embora o sacerdote saiba que para os colonos, ele representa essa ajuda divina que tanto precisam, no fundo, ele deseja ser visto como um ser humano mais, portador das mesmas necessidades e temores que seus fregueses.

A humanização dos personagens que revela a incoerência de sua religiosidade também se manifesta na perspectiva do personagem de José Bernardino dos Santos, um escritor que por não pertencer ao grupo social dos imigrantes, consegue observar e analisar desde outra perspectiva sua cultura em seu intento de entender essas contradições no processo da colonização italiana da Serra Gaúcha. Em suas "Anotações para um romance realista”, o literato apresenta aquela visão do outsider, o sujeito que não pertence ao lugar e por isso consegue enxergar as mesquinharias das famílias em contraste com a experiência de outros lugares.

\section{OS PECADOS VISTOS COM O OLHAR “DE FORA”}

É interessante notar como esse tom crítico que se percebe na ficção de José Clemente Pozenato parece encontrar abrigo nas ideias do escritor peruano Mario Vargas Llosa, o qual, durante um discurso ao receber o prémio Internacional de Novela Rómulo Gallegos, observou: "É preciso [...] adverti-lhes que a literatura é fogo, que ela significa inconformidade e rebelião, que a razão do ser do escritor é o protesto, a contradição e a crítica." (LLOSA, 1967, n.p., tradução nossa). ${ }^{24}$ Essa visão de uma literatura descontente com o mundo é entendida melhor ainda quando Llosa explica como surge a vocação literária:

[...] o escritor tem sido, é e seguirá sendo um descontente. Ninguém que esteja satisfeito é capaz de escrever, ninguém que esteja de acordo, reconciliado com a realidade, cometeria o ambicioso desatino de inventar realidades verbais. A vocação literária nasce do desacordo de um homem com o mundo, da intuição de deficiências, vazios e escórias ao seu redor. (LLOSA, 1967, n.p., tradução nossa). ${ }^{25}$

\footnotetext{
24 “Es preciso [...] advertirles que la literatura es fuego, que ella significa inconformismo y rebelión, que la razón del ser del escritor es la protesta, la contradicción y la crítica".

25 “"...] el escritor ha sido, es y seguirá siendo un descontento. Nadie que esté satisfecho es capaz de escribir, nadie que esté de acuerdo, reconciliado con la realidad, cometería el ambicioso desatino de inventar realidades verbales. La vocación literaria nace del desacuerdo de un hombre con el mundo, de la intuición de deficiencias, vacíos y escorias a su alrededor".
} 
Essas mesmas palavras poderiam descrever a literatura do escritor gaúcho José Clemente Pozenato, uma vez que sua trilogia rompe com o imaginário coletivo. Podemos reafirmar isso com as palavras do próprio escritor, referindo-se à realização de $\mathbf{O}$ quatrilho (obra que conforma a sequência de $\mathbf{A}$ cocanha): "Enquanto objeto construído intencionalmente, ele por um lado incorpora elementos colhidos do imaginário coletivo e, por outro, introduz elementos de transgressão desse imaginário". (POZENATO, 2003, p. 144). De uma maneira inovadora, Pozenato utiliza a literatura para transgredir, por vezes, a memória social predominante e mostrar outras possíveis versões do que poderia ter acontecido. Especificamente em referência à religião dos imigrantes italianos, outras possibilidades são construídas e reveladas no processo histórico da colonização na Serra Gaúcha. Dessa maneira, o autor consegue plasmar com êxito em sua literatura uma versão alternativa da história, que desafia os discursos ufanistas sobre o imigrante italiano, nos quais a religião católica conforma uma parte fundamental. Assim, em lugar de "histórias sagradas" com seus heróis dignos de serem imitados, o Catolicismo é representado por anti-heróis ou heróis derrotados, seres humanos imperfeitos que, ao contrário de sobressaírem por suas virtudes cristãs, sobressaem por suas falhas e incertezas.

Desse modo, o personagem do literato intelectual José Bernardino dos Santos, em A cocanha, pode simbolizar esse papel da literatura que desde uma perspectiva diferente observa a história da colonização italiana para recriá-la de uma maneira crítica. 0 poeta, além de ser uma figura literária reconhecida, também é um sujeito que vem de fora: "Nascido na capital da Província, [...] um homem admirado nos meios literários, trinta e seis anos de idade, vinha embrenhar-se na selva selvagem e áspera, como funcionário da Comissão de Terras" (POZENTO, 2000, p. 173). José Bernardino, pelo fato de ser um indivíduo letrado e estrangeiro, traz esse "olhar de fora", que observa, indaga e reproduz com autoridade a vida dos colonos imigrantes, ou seja, seus costumes, tradições e práticas religiosas na nova terra. Sua posição como intelectual estrangeiro o habilita a realizar uma crítica razoável sobre a realidade dos imigrantes, ressaltando as questões e dilemas que surgem nesse processo. ${ }^{26}$

Um exemplo de como a literatura de José Bernardino se mostra insatisfeita com a realidade observada está em uma de suas reflexões sobre a condição miserável da mulher italiana:

Poder-se-ia pôr, sem receio de hipérbole, que são elas as grandes mártires dessa pobre epopeia de desafortunados. Sobre sofrerem todas as agruras físicas e mentais de seus companheiros, tem

\footnotetext{
${ }^{26}$ Essa identificação de Bernardino com a literatura para analisar, indagar e interpretar uma cultura nos leva a perceber uma possível aproximação entre o personagem e seu criador, o próprio autor de A cocanha, José Clemente Pozenato. Embora a teoria literária em geral não respalde esse tipo de comparação, poderia se argumentar a possível existência de um alter ego do autor, o que se entende como "um segundo eu; substituto perfeito". (HOUAISS, 2009, p. 103). Assim como o escritor ficcional utiliza sua literatura nas Anotações para um romance realista para investigar e analisar o mundo do colono italiano sob uma nova perspectiva, Pozenato, da mesma forma, utiliza seu romance como um instrumento para tentar decodificar a cultura de seus antepassados, sacudindo discursos que formam parte da sociedade colonial italiana, dentre os quais a religião, sem dúvida, ocupa um lugar importante.
} 
acrescida a pena da servidão. [...] Com um acréscimo deprimente: elas sequer são tratadas com consideração, ou algum arremedo de respeito, como na nossa sociedade dita civilizada. Tenho visto maridos aos gritos com suas esposas, em público, [...]. Penaliza-me a sorte dessas mulheres, com seus olhos de azul de safira e seus cabelos dourados de trigo maduro. (POZENATO, 2000, p. 196).

A condição marginada das mulheres imigrantes claramente contrasta com a descrição poética de sua beleza, intensificando a transgressão da imagem popular da mulher italiana como um ser privilegiado e dona do seu lar. ${ }^{27}$

Assim, por ser a mulher colona religiosa retratada no romance como um sujeito desgraciado e infeliz, é possível observar mais uma vez o conceito de sofrimento permeado em sua religiosidade, pois sofrer forma parte de sua devoção cristã e de seus esforços como ser humano para alcançar a graça de Deus (FEUERBACH, 1997, p. 104-106), estando disposta a suportar passivamente todos os maus-tratos, inclusive os de seu próprio marido. ${ }^{28}$

0 teor crítico da representação do processo da imigração italiana por José Bernardino não se limita à condição lamentável da mulher, que compromete o modelo familiar católico, mas também atinge mais uma vez os próprios rituais da religião. A missa, em vez de ser representada como um ritual sagrado, é registrada nas Anotações para um romance realista como um evento mais carnal do que divino. Essa observação percebe-se no seguinte depoimento do poeta:

[...] tenho a impressão de que a missa de domingo é menos uma devoção do que uma oportunidade de vida social e, mesmo, de diversão. Os comerciantes ao redor da praça preparam carnes assadas e põem à venda vinho, cerveja, gasosa, laranjas e até bananas, vendidas a um preço dez vezes maior do que na capital. (POZENATO, 2000, p. 198).

É interessante notar como esse episódio que representa a Igreja como um lugar de negócios nos remete a outro semelhante, encontrado no Novo Testamento,

\footnotetext{
${ }^{27}$ Essa representação miserável da mulher italiana no romance claramente se contrapõe a alguns discursos históricos que a descrevem de uma maneira mitificada. Costa e De Boni (1998, p. 22), embora reconheçam a carga de trabalho excessiva que normalmente era exigida da mulher colona, ponderam: "Não deixa, porém, de ser verdade que as mulheres mandavam e mandam na família. A presença contínua no lar, a autoridade moral de quem não blasfemava e não se embebedava, a dedicação sem limites ao marido e aos filhos colocaram-na em uma situação privilegiada dentro de casa. [...] Por trás de inúmeros traços machistas, nosso grupo italiano vive sob um verdadeiro matriarcado. Nossas 'nonnas' e 'mammas' mandam no lar, no marido e nos filhos, e com razão ouve-se entre os maridos a afirmação: 'là casa, mi son el gal: canto sempre che la parona comanda' (lá em casa, eu sou o galo: canto todas as vezes que a patroa manda)".

${ }^{28}$ Essa atitude disposta a sofrer do religioso para alcançar o favor de Deus, além de ser apoiada por Feuerbach, pode ser correspondida também com os ensinamentos do Catecismo da Igreja Católica (Secção 2, Capítulo 2, Art. 4), o qual apresenta em seu sacramento da Penitência, a necessidade do ser humano de sofrer juntamente com Cristo para completar o processo de expiação de pecados.
} 
no qual Jesus Cristo, ao ver o templo usado com fins lucrativos, reage indignado frente à atitude dos religiosos da época:

\begin{abstract}
Quando Jesus e os discípulos chegaram a Jerusalém, ele entrou no pátio do Templo e começou a expulsar todos os que compravam e vendiam naquele lugar. Derrubou as mesas dos que trocavam dinheiro e as cadeiras dos que vendiam pombas. [...] E ele ensinava assim: - Nas Escrituras Sagradas está escrito que Deus disse o seguinte: “A minha casa será chamada de 'Casa de Oração' para todos os povos". Mas vocês a transformaram num esconderijo de ladrões! (Marcos 11: 15-17, NTLH, 2000).
\end{abstract}

Claramente, tanto a representação fictícia de Pozenato quanto a bíblica deixam uma impressão negativa do uso do espaço religioso. A igreja, em vez de ser utilizada para a administração de sacramentos sagrados, é utilizada para a administração de bens materiais entre comerciantes. Como se esse uso "profano" ainda fosse pouco, as transações financeiras feitas nesse ambiente sacro são desonestas por vender a mercadoria "dez vezes" mais cara do que na capital. A igreja, no romance de Pozenato, assemelha-se a esse "esconderijo de ladrões" apresentado nas Escrituras Sagradas. Aquela definição de Igreja referenciada como uma congregação de homens e mulheres, onde a salvação está presente ${ }^{29}$, cai por terra aos olhos de José Bernardino. ${ }^{30}$ Desse modo, a literatura do escritor fictício pode ser interpretada como outra versão da história que questiona os discursos exaltadores da colonização italiana, incomodando, inquietando e incentivando o leitor a refletir com olho crítico sobre os valores dessa sociedade.

\title{
6. CONSIDERAÇÕES FINAIS
}

O processo de mitificação, como nos mostra Eliade (2006), é um fenômeno vivo que afeta a conduta das sociedades na contemporaneidade assim como ocorreu no passado mais remoto. Em relação ao Catolicismo dos italianos, a mitificação dos sacramentos ocorre historicamente tanto em suas origens na Europa quanto mais tarde no Brasil. Do mesmo modo, a teologia católica cumpre um papel importante nesse processo mitificador da religião dos imigrantes italianos, seja na valorização do sacerdote, seja nos rituais. Essa mitificação sem dúvida aparece no romance $\mathbf{A}$

\footnotetext{
29 “'...] a Igreja, isto é, uma comunidade de homens na qual está presente a salvação. Os sacramentos não são ritos isolados, mas fazem parte da vida da Igreja, que é quem traz a salvação. (NODARI; CESCON, 2009, p. 34).

${ }^{30}$ Neste ponto, pode ser argumentado, segundo o Catolicismo popular, que o conceito de devoção para os imigrantes italianos poderia abarcar também os eventos sociais (como de fato ocorre em outras denominações cristãs). No entanto, aqui se intenta ressaltar a diferença entre o uso físico da igreja para esse tipo de eventos sociais e o uso da igreja como espaço sagrado para a administração dos sacramentos tal como aparecem nas ordenanças da doutrina católica apostólica romana. Além dessa diferença no uso do espaço da igreja, o emprego desonesto de dinheiro nesses eventos religiosos intensifica ainda mais a desmitificação da religião dos imigrantes.
} 
cocanha, de José Clemente Pozenato. No entanto, ela está ali justamente para ser desconstruída a partir do questionamento em torno do comportamento dos homens, das mulheres e dos clérigos.

A ineficácia dos rituais é um dos argumentos da narrativa ficcional empregados para questionar a religião dos imigrantes. As tradições e costumes católicos praticados pelos colonos religiosos não produzem uma transformação do caráter, menos ainda garantem uma conversão genuína de sua parte. Ao contrário, o devoto no romance de Pozenato continua levando a mesma vida miserável e sem esperança. No entanto, ele continua sendo parte dessas práticas porque, ao realizálas, passa também a fazer parte de uma comunidade que confere a ele apoio e identidade de grupo. A religião pode ser assim reduzida ao cumprimento de uma série de regras e tradições, sem que necessariamente exista uma convicção plena do fiel, menos ainda uma transformação de seu caráter.

Desse modo, em A cocanha aparecem famílias destruídas, maridos violentos, autoritários, alcoólicos, adúlteros, esposas oprimidas, marginadas e completamente alienadas. Os personagens na obra do autor são homens e mulheres de carne e osso, vulneráveis a vícios e condutas destrutivas. A figura do padre é igualmente representada como um ser frágil e limitado, que precisa do mesmo apoio que seu rebanho para seguir adiante. Assim, os personagens religiosos de A cocanha são "humanizados", revelados em sua condição de ser humano que tem falhas.

Pozenato, portanto, parte do discurso laudatório da imigração italiana para recriá-lo na representação de sua ficção. Sua versão da história discorda em parte dos registros já estabelecidos ou, pelo menos, como o próprio autor afirma, expõe aquilo que de certa forma incomoda (POZENATO, 1998, p. 114-115). 0 resultado é uma literatura que confronta o leitor e causa certo desconforto, mostrando aspectos contraditórios do processo migratório do colono italiano no qual o Catolicismo, sem dúvida, constitui uma parte essencial de sua cultura.

\section{Referências}

ALLISON, Gregg R. Roman catholic theology and practice: an evangelical assessment.

Illinois: Crossway, 2014.

ALLISON, Gregg. Entrevista (part 4). Disponível em: <reformandainitiative.org>. Acesso em: 5 jan. 2018.

\section{BAREA, José. A vida espiritual nas colônias italianas do estado do Rio Grande} do Sul (1925). Porto Alegre: Edições EST., 1995.

BERNARDI, Mansueto. Colônias e colonizadores (Org. Itálico Marcon). Porto Alegre: EST/Sulina, 1982.

BÍBLIA SAGRADA: Almeida. Revista e Atualizada. São Paulo: Sociedade Bíblica do Brasil, 1999. 
BÍBLIA SAGRADA: Nova tradução na linguagem de hoje. São Paulo: Sociedade Bíblica do Brasil, 2000.

BLAINEY, Geoffrey. Uma breve história do cristianismo. São Paulo: Editora Fundamento

Educacional Ltda., 2012.

BONIATTI, Ilva Maria. Paese de Cuccagna, tradições locais e regionais: a colonização italiana no alto da serra, sul do Brasil. Organon: Revista do instituto de letras da UFRGS. Caxias do Sul, v. 18, n. 37, p. 124-131, 2004.

CATECHISM OF THE CATHOLIC CHURCH. Vaticano: Copyright (C) Libreria Editrice Vaticana. Disponível em: <www.vatican.va/archive/ENG0015/_P38.HTM> Acesso em: 21 agosto. 2020.

COCCO, Ricardo. A questão da religião e a imigração italiana no Rio Grande do Sul. Revista Ciências Humanas. Frederico Westphalen. v. 9., n. 13, p. 9-29. dez. 2008.

CORDEIRO, Tiago. A grande aventura dos jesuítas no Brasil. São Paulo: Planeta, 2016.

COSTA, Rovílio; DE BONI, Luis Alberto. Nós, os gringos. In: Maestri, Mario (Org). Nós, os ítalo-gaúchos. Porto Alegre: Ed. Universidade/UFRGS, 1998. p. 18- 22.

DE CHIRICO, Leonardo. A Christian's Pocket Guide to Papacy. Christian Focus Publications. Edição de Kindle, 2015.

ELIADE, Mircea. Mito e realidade. São Paulo: Perspectiva, 2006.

ELIADE, Mircea. 0 sagrado e o profano: a essência das religiões. São Paulo: Martins Fontes, 1992.

ELIADE, Mircea. Tratado de história das religiões. São Paulo: Martins Fontes, 2008.

FEUERBACH, Ludwig. A essência do cristianismo. 2. ed. Campinas: Papirus, 1997.

GIRON, Loraine Slomp. As nossas avós imigrantes. In: MAESTRI, Mario et al. Nós, os ítalo-gaúchos. 2. ed., Porto Alegre: Ed. Universidade/UFRGS, 1998. p. 92- 94.

HOLMAN BIBLE DICTIONARY. General editor: Trent C. Butler, PH.D. Nashville: Holman Bible Publishers, 1991.

HOUAISS, Antônio; VILLAR, Mauro de Salles. Dicionário Houaiss da língua portuguesa. Rio de Janeiro: Objetiva, 2009. 
KERTZER, David I. Religion and society, 1789-1892. In: The Short Oxford History of Italy: Italy in the nineteenth century. Editado por John A. Davis. Oxford: Oxford University Press,

2000.

LLOSA, Mario Vargas. La literatura es fuego. 1967. Disponível em:

$<$ www.literaterra.com/mariovargasllosa/laliteraturaesfuego $>$. Acesso em: 20 ago. 2018.

MALINOWSKI, Bronislaw. Myth in primitive psychology. London: Read Books Ltd, 2014. Edição de Kindle.

MANFROI, Olívio. A colonização italiana no Rio Grande do Sul: implicações econômicas, políticas e culturais. Porto Alegre: Grafosul Gráfica Editora, 1975.

MOISES, Massaud. Dicionário de termos literários. 12. ed. São Paulo: Cultrix, 2004.

NODARI, Paulo César; CESCON, Everaldo. Os sacramentos na igreja: subsídio teológico-pastoral para formar e educar na fé. São Paulo: Paulus, 2009. (Coleção celebração da fé).

PESAVENTO, Sandra Jatahy. História e literatura: uma velha-nova história. Nuevo Mundo Mundos Nuevos, Debates, 2006.

PIERRARD, PIERRE. História da Igreja. 2. ed. São Paulo: Edições Paulinas, 1982.

POLLARD, John. Catholicism in Modern Italy: religion, society and politics since 1861. London: Routledge, 2008.

POSSAMAI, Paulo. Dall'Italia siamo partiti: a questão da identidade entre os imigrantes

italianos e seus descendentes no Rio Grande do Sul (1875-1945). Passo Fundo: UPF, 2005.

POZENATO, José Clemente. A cocanha. Porto Alegre: Mercado Aberto, 2000.

POZENATO, José Clemente. Processos culturais: reflexões sobre a dinâmica cultural. Caxias do Sul: Educs, 2003.

POZENATO, José Clemente. Uma história do Brasil. In: Maestri, Mario (Org). Nós, os ítalo-gaúchos. Porto Alegre: Ed. Universidade/UFRGS, 1998. p.112-115.

RANGEL, Carlos Roberto da Rosa. Os papeis da mulher na obra $O$ Quatrilho. Itinerários, Araraquara, v. 22, p. 155-171, 2004. 
SEGAL, Robert. Myth: a very short introduction. New York: Oxford University Press, 2004.

SEGNA, Egídio Vittorio. Análise crítica do catolicismo no Brasil e perspectivas para uma pastoral de libertação. Petrópolis: Vozes, 1977.

\section{Para citar este artigo}

ROY, V. A.; ALVES, M. M. Desmitificações da religião católica na obra A Cocanha, de José Clemente Pozenato. Macabéa - Revista Eletrônica do Netlli, Crato, v. 10, n. 3, 2021, p. 152-174.

\section{Os Autores}

VALERIA ACOSTA ROY é mestre em Letras e Cultura pela Universidade de Caxias do Sul (UCS).

MÁRCIO MIRANDA ALVES é professor do mestrado em Letras e Cultura na UCS. 